\title{
Novel ACE2-IgG1 fusions with improved in vitro and in vivo activity against SARS-CoV2
}

Naoki Iwanaga ${ }^{1}$, Laura Cooper ${ }^{2}$, Lijun Rong ${ }^{2}$, Brandon Beddingfield ${ }^{3}$, Jackelyn Crabtree ${ }^{4}$, Ralph

A. Tripp ${ }^{4}$, Xuebin Qin ${ }^{3,5}$, and Jay K. Kolls , $^{1,6}$

${ }^{1}$ Departments of Pediatrics \& Medicine, Center for Translational Research in Infection and Inflammation, Tulane University School of Medicine, New Orleans, LA 70112, USA

${ }^{2}$ Departments of Microbiology and Immunology, College of Medicine University of Illinois at Chicago, Chicago, IL 60612 USA

${ }^{3}$ Departments of Microbiology \& Immunology, Tulane University School of Medicine, New Orleans, LA 70112, USA

${ }^{4}$ Departments of Infectious Diseases, Animal Health Research Center, University of Georgia, Athens, GA 30602 USA

${ }^{5}$ Tulane National Primate Research Center, Covington, LA 70433, USA,

${ }^{6}$ Lead contact 


\section{Abstract}

SARS-CoV2, the etiologic agent of COVID-19, uses ACE2 as a cell entry receptor. Soluble ACE2 has been shown to have neutralizing antiviral activity but has a short half-life and no active transport mechanism from the circulation into the alveolar spaces of the lung. To overcome this, we constructed an ACE2-human IgG1 fusion protein with mutations in the catalytic domain of ACE2. This fusion protein contained a LALA mutation that abrogates Fcr $\gamma$ binding, but retains FCRN binding to prolong the half-life, as well as achieve therapeutic concentrations in the lung lavage. Interestingly, a mutation in the catalytic domain of ACE2, MDR504, completely abrogated catalytic activity, but significantly increased binding to SARSCoV2 spike protein in vitro. This feature correlated with more potent viral neutralization in a plaque assay. Parental administration of the protein showed stable serum concentrations with a serum half-life of $\sim 145$ hours with excellent bioavailability in the epithelial lining fluid of the lung. Prophylactic administration of MDR504 significantly attenuated SARS-CoV2 infection in a murine model. These data support that the MDR504 hACE2-Fc is an excellent candidate for pre or post-exposure prophylaxis or treatment of COVID-19. 


\section{Introduction}

SARS-CoV-2 is the etiologic agent of the current COVID-19 pandemic. Similar to SARS-CoV and other betacoronaviruses it uses the angiotensin-converting enzyme 2 (ACE2) receptor [1]. ACE2 is expressed in the nasal respiratory epithelium, in the conducting airway in type II pneumocytes [2] and elsewhere [3]. It has been hypothesized that the spike protein of SARSCoV-2 has stronger binding to human ACE2 compared to SARS-CoV $[4,5]$. Recent surface plasmon resonance assays with soluble ACE2 binding SARS-COV-2 spike protein had a binding affinity in the $\mathrm{nM}$ to $\mathrm{pM}$ range [6]. Thus, the soluble version of ACE2 may have potent viral neutralization activity. ACE2 is a type I transmembrane domain with a 740 amino acid ectodomain [7]. Soluble ACE2 has been shown to bind to SARS-CoV and SARS-CoV-2 spike proteins and block viral entry [8]. Soluble ACE2 has been administered to humans with pulmonary hypertension [9] and acute respiratory distress syndrome (ARDS) [10] at dose ranges of 0.1 to $0.8 \mathrm{mg} / \mathrm{kg}$ and shown to be well tolerated. However, the pharmacokinetic/pharmacodynamic (PK/PD) of soluble ACE2 is not ideal for sustained viral neutralization in vivo and is not engineered to be transported from the circulation into the epithelial lining fluid of the lung. ACE2-IgG Fc fusion proteins have been reported to also bind virus and neutralize SARS-CoV-2 pseudoviruses in vitro [6]. Moreover, several mutants in the catalytic domain have been reported that also bind and neutralize virus [6]. However, ACE2-IgG Fc fusion proteins retain FcR $\gamma$ binding which may compromise serum stability or activate FcR $\gamma$ on myeloid cells, which may be problematic in COVID-19.

Thus, we engineered four distinct ACE2-FC IgG1 fusions all with the LALA mutation to abrogate FcR $\gamma$ binding but retain binding to the neonatal Fc receptor which is important for serum stability [11] as well as transport into the lung [12]. In addition to the wild-type ACE2 ectodomain, we engineered several mutations to inactivate catalysis of angiotensin such as MDR504 and MDR505. Constructs included an IgGk leader sequence and an IEGR linker between ACE2 and 
the $\mathrm{CH} 2$ and $\mathrm{CH} 3$ domains of human IgG1. All constructs expressed proteins consistent with homodimers after transfection in HEK293 cells. All constructs bound monomeric SARS-CoV-2 receptor binding domain as well as trimeric spike protein [13]. However, the binding of the MDR504 mutant was superior at both room temperature and $37^{\circ} \mathrm{C}$. This correlated with enhanced neutralization of virus in a Vero E6 cell plaque assay. Furthermore, the MDR504 mutant had similar serum stability as wild-type ACE2-Fc but appears to have higher levels in the epithelial lining fluid of the lung after parenteral administration to C57BI/6 mice. Based on these studies, the MDR504 mutant appears to be an excellent candidate to move forward in terms of preventing or treating COVID-19.

\section{Methods}

\section{Mice}

Female wild type C57BL/6J mice 6-10-week-old were used for in vivo studies. The mice were bred in-house or purchased from The Jackson Laboratory. All experiments were performed using sex- and age-matched controls and approved by the Institutional Animal Care and Use Committee of Tulane University.

\section{Generation of different constructs of human ACE2 fusion proteins}

The DNA sequences of the extracellular domains of ACE2 and IgG1 were synthesized by Genscript and cloned into pcDNA3.1. Transient transfection was performed using Lipofectamine $^{\mathrm{TM}} 3000$ Transfection Reagent (Invitrogen) in 293T cells. The collected supernatants were collected and purified by protein G-sepharose (Thermo Fisher). The 
concentration and purity were confirmed by measuring the UV absorbance at wavelength of 280 nm, BCA assay (Thermo Fisher) and human IgG ELISA (Thermo Fisher).

\section{Western blotting}

Following the removal of the supernatants, cell lysates were dissolved in PBS $(50 \mathrm{mg} / \mathrm{ml})$ containing protease inhibitors (Thermo Scientific) and 1 mM PMSF. BCA assay was performed to quantify protein and $5.0 \mu \mathrm{g}$ protein was used for Western blotting. Western blots were performed using 7.5\% SDS-PAGE gels (Bio-Rad) under the non-reducing or reducing condition with 2.5\% 2-mercaptoethanol and transferred to PVDF membranes. The blot was probed with goat anti-human IgG-HRP (Southern Biotech). After incubation with IgG-HRP-conjugated antihuman antibody, membranes were washed and incubated with SuperSignal West Pico Chemiluminescent Substrate (Thermo Scientific). Signal was detected using Bio-Rad ChemiDoc MP imaging system.

\section{ELISA for human ACE2 and spike protein}

ELISA plates were coated with $2 \mu \mathrm{g} / \mathrm{mL}$ recombinant spike glycoprotein receptor binding domain (RBD) from SARS-CoV-2 (BEI RESOURCES) or recombinant S1 subunit (RayBiotech) overnight at $4{ }^{\circ} \mathrm{C}$. Coated plates were washed with washing buffer (0.05\% Tween 20 in PBS), blocked for $2 \mathrm{~h}$ at room temperature with blocking buffer (1\% BSA and 0.1\% Tween 20 in PBS), and washed before the addition of the supernatants or cell lysates from transfected 293T cells. After $2 \mathrm{~h}$ incubation at RT, or $1 \mathrm{~h}$ incubation at $37^{\circ} \mathrm{C}$, the plates were washed and incubated with goat anti-human IgG conjugated with horseradish peroxidase (Southern Biotech) diluted $1 / 5,000$ in assay diluent (0.5\% BSA and 0.05\% Tween 20 in PBS) for $1 \mathrm{~h}$ at RT, or for 30 min at 
$37^{\circ} \mathrm{C}, \mathrm{TMB}$ peroxidase substrate (Southern Biotech) was added to each well. Absorbance was read at $450 \mathrm{~nm}$ on a microplate reader (BioTek).

\section{Pseudovirus Production}

Pseudoviruses for antibody screening were generated using the following plasmids: S-Tag of SARS (pcDNA3.1(+)-SARS-S), S-Tag of SARS2 (pcDNA3.1(+)-SARS2-S), vesicular stomatitis virus (pcDNA3.1(+)-VSV-G), and the HIV-1 pro-viral vector pNL4-3.Luc.R-E- which were obtained through the NIH AIDS Research and Reference Reagent Program. All pseudoviruses were produced by transient co-transfection of 293 T cells using a polyethyleneimine (PEI)-based transfection protocol. Five hours after transfection, cells were washed with phosphate-buffered saline (PBS), and $20 \mathrm{~mL}$ of fresh media was added to each $150 \mathrm{~mm}$ plate. Twenty-four hours post transfection, the supernatant was collected and filtered through a $0.45 \mu \mathrm{M}$ pore size filter and stored at $4{ }^{\circ} \mathrm{C}$ prior to use.

\section{Antibody neutralization Assay}

Targeted 293T cells were transfected with pcDNA3.1(+)-humanACE2 and pCSDest-TMPRSS2 plasmids for $6 \mathrm{~h}$. The cells were then trypsinized and seeded $1 \times 10^{5}$ cells/well in DMEM complete into 96 -well plates $\left(100 \mu \mathrm{L} /\right.$ well) then incubated for 16 hours at $37{ }^{\circ} \mathrm{C}$ and $5 \% \mathrm{CO}_{2}$. SARS-1, SARS-2, and VSV pseudoviruses were incubated with the test samples at room temperature for $1 \mathrm{~h}$, and then added to the target cells in 96-well plates. Plates were incubated for 48 hours and levels of viral infection were determined by luminescence using the neolite reporter gene assay system (PerkinElmer). Virus alone was used as a control and data was normalized to the control. 


\section{Human ACE2 neutralization of SARS-CoV2 by plaque assay}

Vero E6 cells were plated in a 6 well plate at $8 \times 10^{5}$ cells per well and incubated overnight. Each construct of hACE2-Fc was preincubated with SARS-CoV2 virus for 10 minutes before infection in $1 \mathrm{ml}$ media. The cells were washed once with PBS and infected at a MOI of 0.01 with the compounds for $1 \mathrm{~h}$. Following infection, the supernatants containing the virus and compounds were removed and $3 \mathrm{ml}$ overlay media containing each compound were added to the wells and incubated for additional 4 days. Post infection, the cells were fixed and stained to visualize plaques.

\section{Pharmacokinetics study}

Mice were injected with $4 \mathrm{mg} / \mathrm{kg}$ body weight MDR504 via retro-orbital (i.v.) and then the serums and bronchoalveolar lavage fluid were collected at each time point. The concentration of MDR504 were analyzed by detecting IgGFc by ELISA. We used purified anti-human IgG Fc antibody (Biolegend) as a capture antibody and anti-Human IgG Fc, Multi-Species SP ads-HRP (SouthrenBiotech) as a detection antibody and the other procedure is same as mentioned above.

\section{In vivo evaluation of MDR504.}

All animals are cared for in accordance with the NIH guide to Laboratory Animal Care. The Institutional Biosafety Committee approved the procedures for sample handling, inactivation, and removal from a BSL3 containment. For this study, we utilized the murine model of SARSCoV2 were C57BI/6 mice were first inoculated with adenovirus encoding human ACE2 (Vector Biolabs). Four days later, mice received $5 \times 10^{4}-2 \times 10^{5}$ pfu of SARS-CoV-2 intranasally. To 
evaluate MDR504, mice were dosed with wild-type hACE2-Fc or MDR504 three to four hours prior to SARS-CoV2 infection. Mice were euthanized 72 hours post infection, tissue samples were collected in Zinc formalin (Anatech), embedded in paraffin and 5 um thick sections were cut, adhered to charged glass slides. 5um sections of Zinc Formalin-fixed, paraffin-embedded lung were mounted on charged glass slides, baked overnight at $560 \mathrm{C}$ and passed through Xylene, graded ethanol, and double distilled water to remove paraffin and rehydrate tissue sections. A microwave was used for heat induced epitope retrieval. Slides were heated in a high pH solution (Vector Labs $\mathrm{H}-3301$ ), rinsed in hot water and transferred to a heated low $\mathrm{pH}$ solution (Vector Labs H-3300) where they were allowed to cool to room temperature. Sections were washed in a solution of phosphate-buffered saline and fish gelatin (PBS-FSG) and transferred to a humidified chamber. Tissues were blocked with 10\% normal goat serum (NGS) for 40 minutes, followed by a 60 minute incubation with polyclonal guinea pig anti-SARS-CoV1 antibodies (1:1000) (NR-10361, BEI Resoruces). Slides were transferred to the humidified chamber and incubated, for 40 minutes, with secondary antibodies tagged with various Fluor fluorochromes and diluted to a working concentration of $2 \mathrm{ug} / \mathrm{mL}$. Slides were mounted using a homemade anti-quenching mounting media containing Mowiol (Calbiochem \#475904) and DABCO (Sigma \#D2522) and imaged with a Zeiss Axio Slide Scanner.

\section{Statistical analysis}

Statistical analysis was performed with GraphPad Prism 8.0. P values $<0.05$ was evaluated statistically significant. Comparisons between two normally distributed groups were performed by simple 2-tailed unpaired student's t-test. For multiple groups comparisons, we used one-way or two-way ANOVA with Tukey's post-hoc analysis. Values are represented as means \pm SEM. P values are annotated as follows $\left({ }^{*}\right) \leq 0.05,\left({ }^{* *}\right) \leq 0.01,\left({ }^{* * *}\right) \leq 0.001$, and $\left(^{* * * *}\right) \leq 0.0001$. 


\section{Results}

\section{Expression of hACE2-Fc constructs}

The amino acid sequences are listed in Supplemental Table I. After transient transfection of the constructs into 293 T cells, human IgG was readily detected by ELISA (data not shown). Proteins were run on a reduced SDS-PAGE gel and migrated at $\sim 140 \mathrm{kDa}$ consistent with the predicted molecular weight of the monomer (Supplementary Figure 1A). SDS-PAGE analysis in non-reducing conditions revealed migration consistent with a dimeric protein (Supplementary Figure 1B).

\section{SARS-CoV2 RBD and Spike Binding}

Proteins were purified from the supernatant of $293 \mathrm{~T}$ cells, and we assayed binding to immobilized RBD or spike by ELISA. In experiments run at room temperature, we observed higher binding of the MDR504 and MDR505 hACE2-Fc and a lesser extent to the MDR503 hACE2-Fc compared to wild-type ACE2-Fc (Figure 1A and B). This increase in binding was more dramatic when assayed at $37^{\circ} \mathrm{C}$ (Figure $1 \mathrm{C}$ and D) where binding of the MDR504 mutant was superior for the both RBD assay as well against the trimeric spike protein. To verify that the MDR504 mutant lacked ACE2 catalytic activity we performed an in vitro catalysis assay using a fluorogenic peptide that contains an ACE2 cleavage site. WT ACE2 showed substantial catalysis of the peptide whereas the MDR504 mutant completely lacked any detectable activity (Figure 1E).

\section{Neutralization of SARS-CoV2 infection}

Using a pseudotyped model of SARS-CoV-2 we found superior neutralization with the MDR504 mutant and the MDR505 double mutant compared to wild type human ACE2 Fc IgG1 (Figure 2A, 2B). Next, we examined neutralization of SARS-CoV-2 using a plaque assay in Vero E6 cells. Initial studies were done at $50 \mu \mathrm{g} / \mathrm{ml}(223 \mathrm{nM})$ based on studies with Pavalizumab, an 
anti-RSV monoclonal antibody, showed that effective anti-RSV trough concentrations in vivo were $\sim 40 \mu \mathrm{g} / \mathrm{ml}$ [14]. $50 \mu \mathrm{g} / \mathrm{ml}$ completely neutralized SARS-CoV-2 in vitro (Figure 2C). Similar, but slightly less activity was observed with the MDR503 mutant (Figure 2C). Next, we compared the wild-type protein to the dual mutant MDR505 and the MDR504 mutant at the lower concentration of 1 and $10 \mu \mathrm{g} / \mathrm{ml}$. Here, both mutants neutralized the virus and considerably improved over the wild-type protein (Figure 2D). Moreover, we confirmed the significant improvement in the $\mathrm{IC}_{50}$ of the MDR504 mutant (Figure 2E).

\section{Serum Stability and BAL Fluid Concentrations}

C57BL/6 mice were injected with wild-type ACE2-Fc or the MDR504 mutant and serum was collected at $0,1,24$, or $72 \mathrm{~h}$. Mice were euthanized at $6 \mathrm{~h}$ and $72 \mathrm{~h}$ and underwent bronchoalveolar lavage (BAL) to measure ACE2-Fc in the lung. The MDR504 mutant had a slightly higher peak concentration in serum and a half-life of approximately $145 \mathrm{~h}$ (Figure 3A0. The MDR504 mutant had slightly higher concentrations in BALF at $72 \mathrm{~h}$ compared to the wildtype protein (Figure 3B).

\section{In vivo efficacy experiments.}

Histological analysis of vehicle treated mice showed widespread SARS-COV2 infection in the distal lung with approximately $4 \%$ of the cells infected (Figure X). This was largely unaffected by wild-type ACE2-Fc prophylaxis. In contrast, MDR504 had significantly less infected cells with only $0-1 \%$ of cells positive for SARS-CoV2 staining (Figure $\mathrm{X}$ ). 


\section{Discussion}

One mechanism that has made SARS-CoV-2 more infectious than the 2002 SARS-CoV epidemic is potentially the higher affinity of SARS-CoV-2 spike protein to the human ACE2 [4, 5]. However, this increased affinity represents a potential therapeutic target to block viral entry. To this end, we made ACE2-Fc fusions with mutations in the ACE2 catalytic domain as well as in the IgG1 constant region to abrogate FcR $\gamma$ binding. Interestingly, we found that the MDR504 mutation had greater binding the SARS-CoV-2 RBD and spike protein. This translated to a lower $\mathrm{IC}_{50}$ value for infectious viral neutralization and in a pseudovirus assay. At this time, the structural basis for this remains unclear. Cryo-EM studies of SARS-CoV-2 RBD has been shown to bind the $\mathrm{NH} 2$ terminus of human ACE2 [15]. However, the RBD also binds to residues K353, G354, and D355 [15] and thus it is possible that the MDR504 mutation affects this binding. The other reported ACE2-Fc mutants showed equivalent binding and pseudovirus neutralization [6]. The authors of this paper made $\mathrm{H} 374 \mathrm{~N}$ and $\mathrm{H} 378 \mathrm{~N}$ mutations that have putatively reduced ACE2 catalytic activity but that was not specifically assayed as part of their study [6]. However, our $I C_{50}$ data is in agreement with their calculated $K_{d}$ using surface plasmon resonance where the $K_{d}$ was reported to be $11.2 \mathrm{nM}$ [6]. Thus, the MDR504 mutation may have a structural basis for enhanced neutralization over wild-type ACE2 and that will be the subject of future research. Importantly our constructs also showed activity against infectious SARS-CoV2. The MDR504 mutant also showed excellent stability in serum and achieved therapeutic levels in bronchoalveolar lavage (BAL) fluid in a murine PK/PD study.

Taken together, this reagent may be useful as pre- or post-exposure prophylaxis or as therapy for COVID-19. This technology may also complement vaccine technology, as it may be useful in subjects that may not be good candidates for vaccines such as patents with hematologic or other malignancies, or those that are undergoing immunosuppressive therapy for organ transplantation or autoimmune disease. 


\section{Acknowledgements}

This work was supported by the following NIH grant R35HL139930 (JK) and R21OD024931

(XQ). The following reagent was produced under HHSN272201400008C and obtained through

BEI Resources, NIAID, NIH: Spike Glycoprotein Receptor Binding Domain (RBD) from SARS-

Related Coronavirus 2, Wuhan-Hu-1, Recombinant from HEK293 Cells, NR-52306. We are

grateful for technical help from Cecily C Midkiff and Dr. Robert Blair in the histological core of

Tulane National Primate Research Center and Christopher J Monjure in the Tulane ABSL3

core. 


\section{References}

1. Xu H, Zhong L, Deng J, Peng J, Dan H, Zeng X, et al. High expression of ACE2 receptor of 2019-nCoV on the epithelial cells of oral mucosa. Int J Oral Sci. 2020;12(1):8. Epub 2020/02/26. doi: 10.1038/s41368-020-0074-x. PubMed PMID: 32094336; PubMed Central PMCID: PMCPMC7039956.

2. Hou YJ, Okuda K, Edwards CE, Martinez DR, Asakura T, Dinnon KH, 3rd, et al. SARSCoV-2 Reverse Genetics Reveals a Variable Infection Gradient in the Respiratory Tract. Cell. 2020. Epub 2020/06/12. doi: 10.1016/j.cell.2020.05.042. PubMed PMID: 32526206.

3. Hoffmann M, Kleine-Weber H, Schroeder S, Kruger N, Herrler T, Erichsen S, et al. SARS-CoV-2 Cell Entry Depends on ACE2 and TMPRSS2 and Is Blocked by a Clinically Proven Protease Inhibitor. Cell. 2020;181(2):271-80 e8. Epub 2020/03/07. doi: 10.1016/j.cell.2020.02.052. PubMed PMID: 32142651; PubMed Central PMCID: PMCPMC7102627.

4. Shang J, Ye G, Shi K, Wan Y, Luo C, Aihara H, et al. Structural basis of receptor recognition by SARS-CoV-2. Nature. 2020. Epub 2020/04/01. doi: 10.1038/s41586-020-2179-y. PubMed PMID: 32225175.

5. Yan R, Zhang Y, Li Y, Xia L, Guo Y, Zhou Q. Structural basis for the recognition of SARS-CoV-2 by full-length human ACE2. Science. 2020;367(6485):1444-8. Epub 2020/03/07. doi: 10.1126/science.abb2762. PubMed PMID: 32132184; PubMed Central PMCID: PMCPMC7164635.

6. Lei C, Qian K, Li T, Zhang S, Fu W, Ding M, et al. Neutralization of SARS-CoV-2 spike pseudotyped virus by recombinant ACE2-Ig. Nat Commun. 2020;11(1):2070. Epub 2020/04/26. doi: 10.1038/s41467-020-16048-4. PubMed PMID: 32332765.

7. Crackower MA, Sarao R, Oudit GY, Yagil C, Kozieradzki I, Scanga SE, et al. Angiotensin-converting enzyme 2 is an essential regulator of heart function. Nature. 2002;417(6891):822-8. Epub 2002/06/21. doi: 10.1038/nature00786. PubMed PMID: 12075344. 8. Monteil V, Kwon H, Prado P, Hagelkruys A, Wimmer RA, Stahl M, et al. Inhibition of SARS-CoV-2 Infections in Engineered Human Tissues Using Clinical-Grade Soluble Human ACE2. Cell. 2020. Epub 2020/04/26. doi: 10.1016/j.cell.2020.04.004. PubMed PMID: 32333836; PubMed Central PMCID: PMCPMC7181998.

9. Hemnes AR, Rathinasabapathy A, Austin EA, Brittain EL, Carrier EJ, Chen X, et al. A potential therapeutic role for angiotensin-converting enzyme 2 in human pulmonary arterial hypertension. Eur Respir J. 2018;51(6). Epub 2018/06/16. doi: 10.1183/13993003.02638-2017. PubMed PMID: 29903860; PubMed Central PMCID: PMCPMC6613216.

10. Khan A, Benthin C, Zeno B, Albertson TE, Boyd J, Christie JD, et al. A pilot clinical trial of recombinant human angiotensin-converting enzyme 2 in acute respiratory distress syndrome. Crit Care. 2017;21(1):234. Epub 2017/09/08. doi: 10.1186/s13054-017-1823-x. PubMed PMID: 28877748; PubMed Central PMCID: PMCPMC5588692.

11. Arduin E, Arora S, Bamert PR, Kuiper T, Popp S, Geisse S, et al. Highly reduced binding to high and low affinity mouse Fc gamma receptors by L234A/L235A and N297A Fc mutations engineered into mouse IgG2a. Mol Immunol. 2015;63(2):456-63. Epub 2014/12/03. doi: 10.1016/j.molimm.2014.09.017. PubMed PMID: 25451975.

12. Kolls JK, Lei D, Greenberg S, Nelson S, Beutler B. Adenovirus-mediated blockade of tumor necrosis factor in mice protects against endotoxic shock yet impairs pulmonary host defense. JInfectDis. 1995;171:570-5.

13. Amanat F, Stadlbauer D, Strohmeier S, Nguyen THO, Chromikova V, McMahon M, et al. A serological assay to detect SARS-CoV-2 seroconversion in humans. Nature medicine. 2020. Epub 2020/05/14. doi: 10.1038/s41591-020-0913-5. PubMed PMID: 32398876. 
bioRxiv preprint doi: https://doi.org/10.1101/2020.06.15.152157; this version posted July 24,2020 . The copyright holder for this preprint (which

was not certified by peer review) is the author/funder, who has granted bioRxiv a license to display the preprint in perpetuity. It is made available under aCC-BY-NC-ND 4.0 International license.

14. Beeler JA, van Wyke Coelingh K. Neutralization epitopes of the F glycoprotein of respiratory syncytial virus: effect of mutation upon fusion function. J Virol. 1989;63(7):2941-50. Epub 1989/07/01. PubMed PMID: 2470922; PubMed Central PMCID: PMCPMC250848. 15. Lan J, Ge J, Yu J, Shan S, Zhou H, Fan S, et al. Structure of the SARS-CoV-2 spike receptor-binding domain bound to the ACE2 receptor. Nature. 2020;581(7807):215-20. Epub 2020/04/01. doi: 10.1038/s41586-020-2180-5. PubMed PMID: 32225176. 


\section{Figure Legends}

Figure 1. In vitro biding of MDR504. Binding of RBD (A, C) or spike protein (B, D) and hACE2 by ELISA. Assays were performed at room temperature $(A, B)$ or at $37^{\circ} \mathrm{C}(\mathrm{C}, \mathrm{D})$. (E) Catalytic activity of WT or the MDR504 mutant in a fluorogenic ACE2 assay $(n=3)$. Significant differences are designated using one-way ANOVA followed by Tukey's multiple comparisons test $(B, D)$ and unpaired t-test $(E)$ based on the AUC. *, $P<0.05 ;{ }^{* *}, P<0.01 ;{ }^{* *}, P<0.001$.

Figure 2. In vitro efficacy of MDR504. Neutralization of pseudovirus were compared among the different constructs in (A) $89 \mathrm{nM}$ and (B) $223 \mathrm{nM}$ of various hACE2-IgG1 fusions. MDR504 mutant and MDR505 double mutant showed significantly higher neutralization. Similarly, SARSCoV2 neutralization with WT and MDR503 mutant at $223 \mathrm{nM}$ attested the result by plaque assay (C). $\mathrm{IC}_{50}$ of the different ACE2-IgG1 fusions in the placque assay (D). Significant differences are designated using one-way ANOVA (A, B, C) and two-way ANOVA (D) followed by Tukey's multiple comparisons test. *, $\mathrm{P}<0.05$; ${ }^{* *}, \mathrm{P}<0.01$; ${ }^{\star \star \star}, \mathrm{P}<0.001$; ${ }^{\star \star \star *}, \mathrm{P}<0.0001$. (E) Calculated $\mathrm{IC}_{50}$ of each construct based on the placque assay data.

Figure 3. In vivo PK of MDR504. In vivo pharmacokinetics of the WT and MDR504 mutant ACE2-IgG1 was assayed after intravenous injection of $4 \mathrm{mg} / \mathrm{kg}$ body weight of protein assayed in in serum $(A)$ and $B A L$ fluid $(B)$.

Figure 4. In vivo efficacy of MDR504. C57BI/6 mice were administered AdhACE2. 4 days later mice were treated with vehicle, or $15 \mathrm{mg} / \mathrm{kg} \mathrm{WT-ACE2} \mathrm{or} \mathrm{mutant} \mathrm{ACE2-IgG1} \mathrm{IV.} 4$ hours later mice were infected intranasally with SARS-Cov2. Mice were euthanized three days post SARS-CoV2 inoculation in ABSL3. SARS-CoV2 infection was assayed by IFC. 
bioRxiv preprint doi: https://doi.org/10.1101/2020.06.15.152157; this version posted July 24,2020 . The copyright holder for this preprint (which

was not certified by peer review) is the author/funder, who has granted bioRxiv a license to display the preprint in perpetuity. It is made available under aCC-BY-NC-ND 4.0 International license.

Supplementary Figure 1. (A) Western blotting under reducing condition with $2.5 \%$ 2-

mercaptoethanol of hACE2 expression in cell supernatants of transfected cells as well as cell

lysates. (B) Western blotting of hACE2-IgG1 without reducing conditions. 


\section{Figure 1.}

A

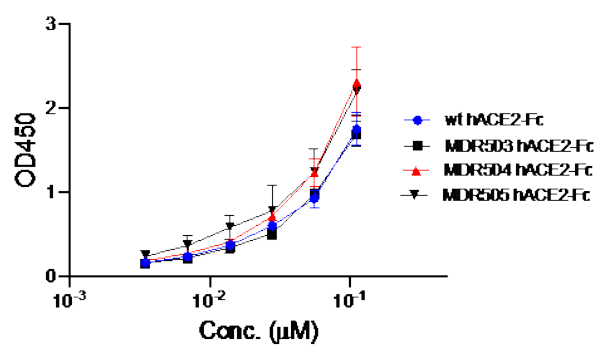

C

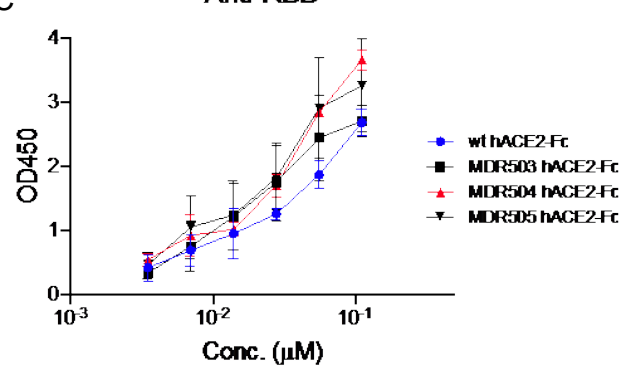

Anti-RBD

Conc. (IM)

E

B

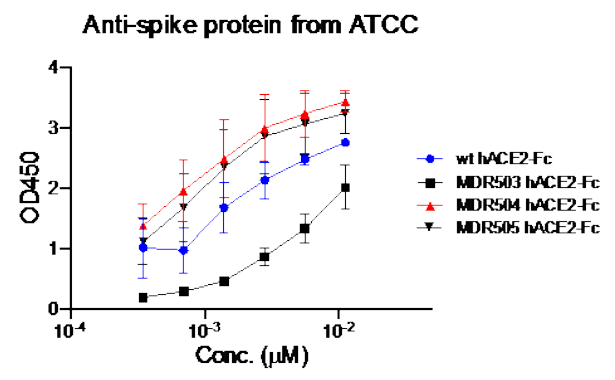

D Anti-spike protein from ATCC

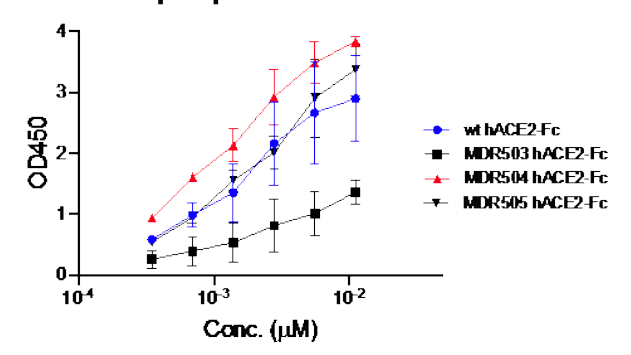

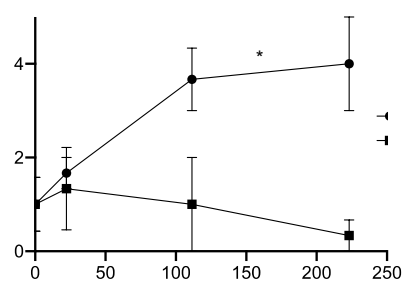




\section{Figure 2.}
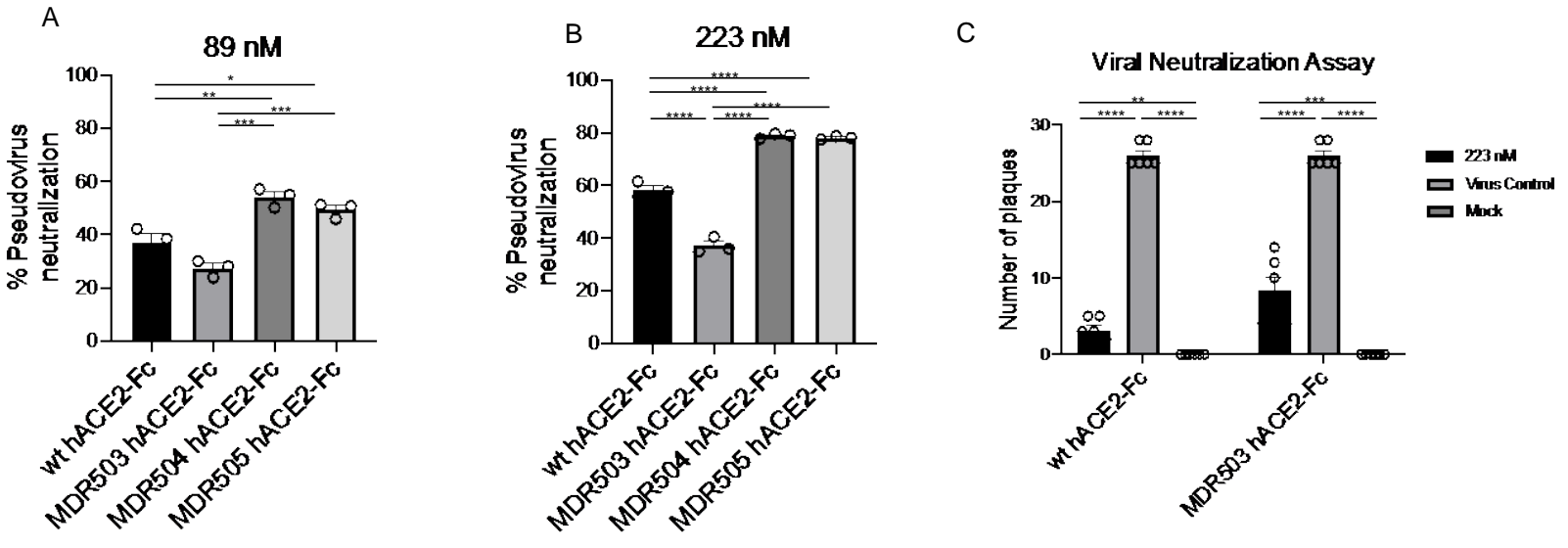

D

Viral Neutralization Assay

E

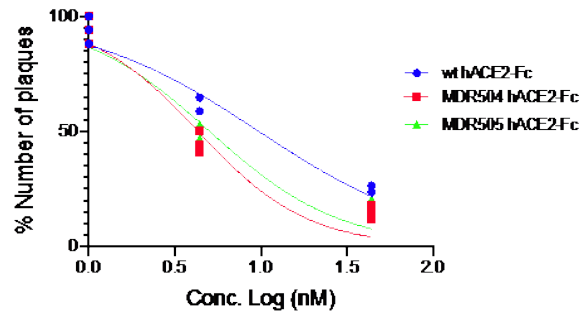

\begin{tabular}{l|c|} 
& $I_{50}(\mathrm{nM})$ \\
\hline wt hACE2-Fc & 9.725 \\
\hline MDR503 hACE2-FC & 57.48 \\
\hline MDR504 hACE2-Fc & 4.313 \\
\hline MDR505 hACE2-Fc & 5.036
\end{tabular}




\section{Figure 3.}

A

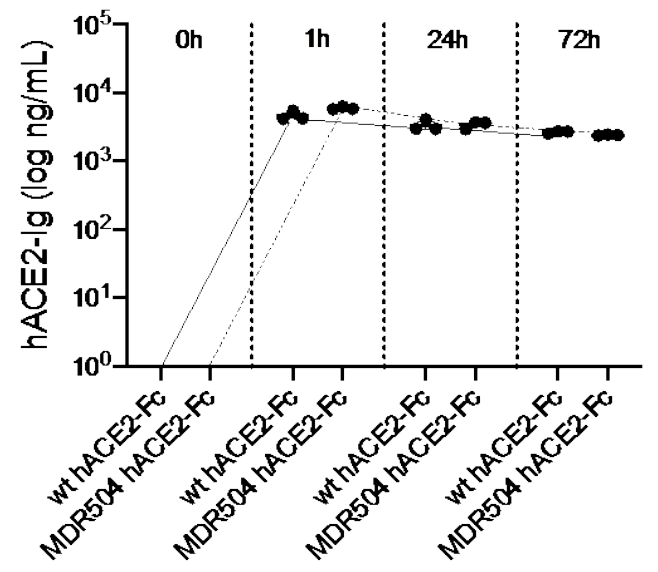

B

\section{hACE2-Fc in BALF}

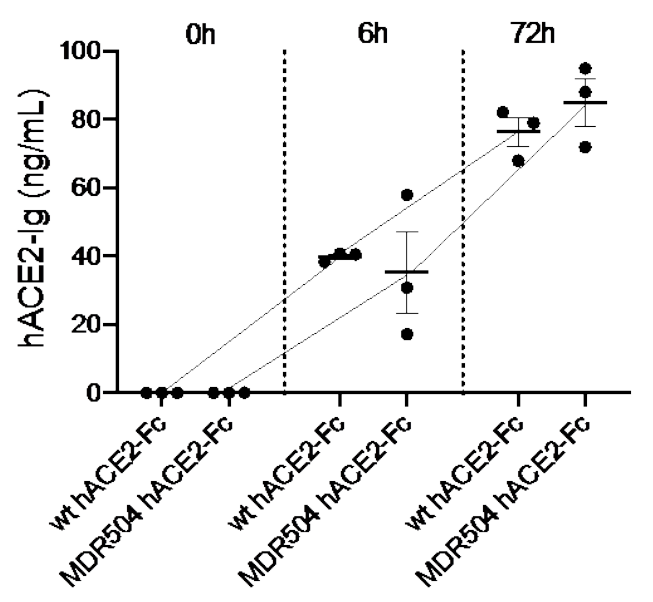


bioRxiv preprint doi: https://doi.org/10.1101/2020.06.15.152157; this version posted July 24, 2020. The copyright holder for this preprint (which was not certified by peer review) is the author/funder, who has granted bioRxiv a license to display the preprint in perpetuity. It is made available under aCC-BY-NC-ND 4.0 International license.

\section{Figure 4.}

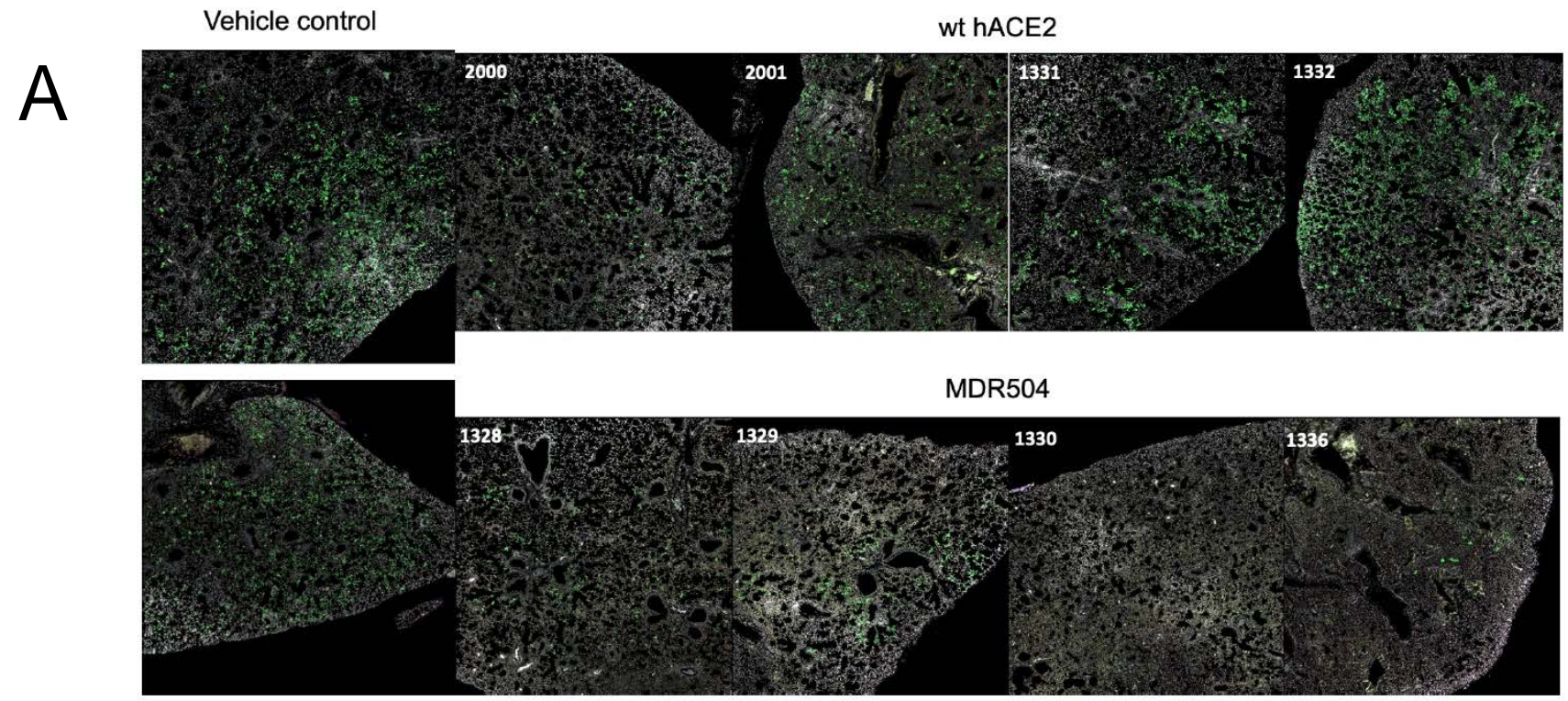

\section{CoV2 cell percentage}

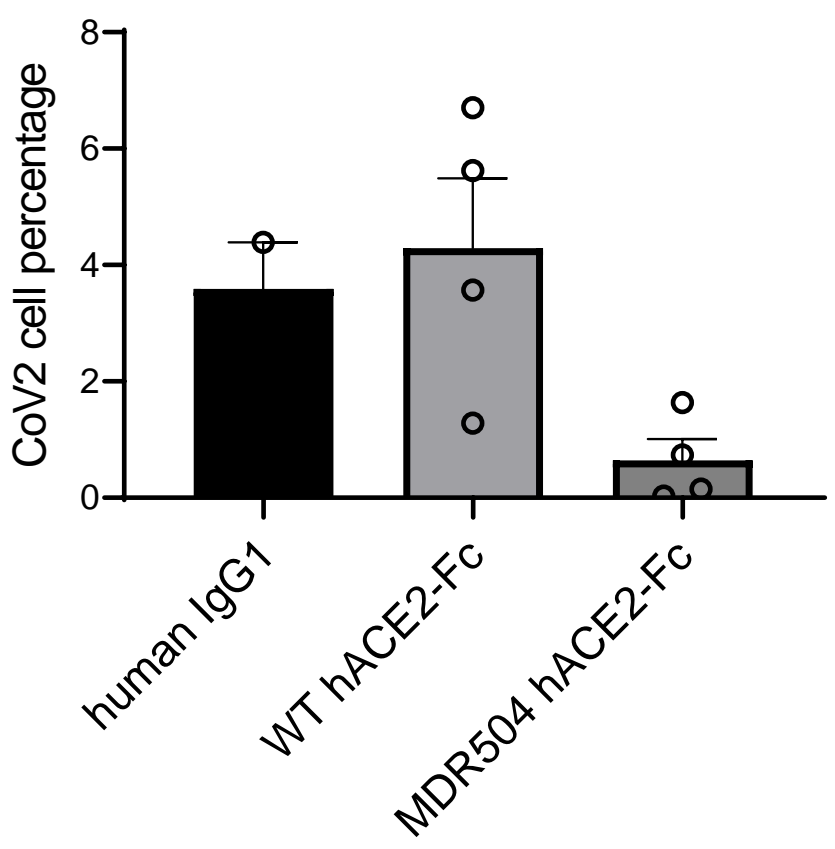


bioRxiv preprint doi: https://doi.org/10.1101/2020.06.15.152157; this version posted July 24, 2020. The copyright holder for this preprint (which was not certified by peer review) is the author/funder, who has granted bioRxiv a license to display the preprint in perpetuity. It is made available under aCC-BY-NC-ND 4.0 International license.

\section{Supplementary Figure 1.}

A

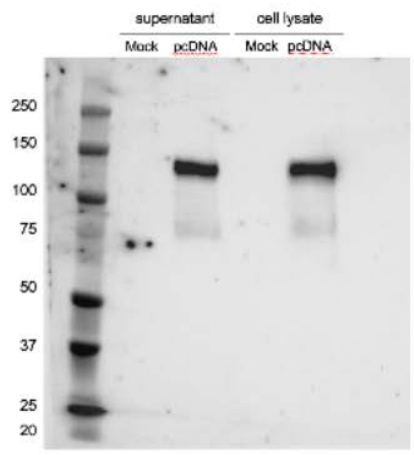

B

supermatant cell lysate

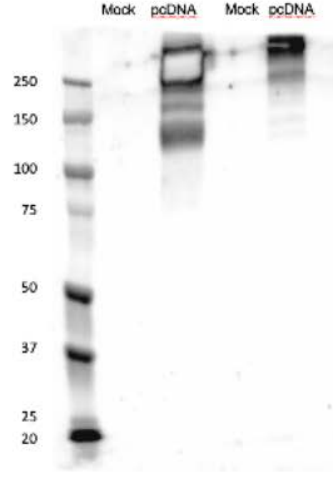

